\section{FIRST SIR JOSEPH J. THOMSON MEMORIAL LECTURE}

$\mathrm{W}$ ITHIN the generous curve of Faraday's horseshoe table at the Royal Institution, almost every distinguished man of science has stood, at some time or another during the last hundred odd years, to deliver a "Friday Evening", or some other discourse. Some have been grim, and some have been gay, but none have been both in perhaps quite the same sense as Sir Joseph John Thomson.

The recent memorial lecture, under the auspices of the Chemical Society, given on April 16 from the same spot by the son of his predecessor in the Cavendish chair at Cambridge, is no ordinary tribute. Lord Rayleigh has produced something at once personal and vivacious, but at the same time historical. Three parts, very unequal in length, but all valuable, may be discerned. The first is biographical and completely charming. (Who can possibly forget 'J. J.' pushing his glasses up on to his forehead to look at something close at hand ?) The second is, in effect, largely an account of the search for the electron, and contrives to make the period 1870-1905 live again in retrospect. The third and shortest, depicts 'J. J.' as Master of Trinity. Many perhaps will wish that it had been longer, but for all that, one is glad to have it just as it is.

Our task now, however, is to meditate afresh upon the thirty-five years of activity to which Lord Rayleigh devotes the bulk of his address. Nevertheless, it is scarcely feasible to do this, without first of all recognizing the extraordinary intellectual strength possessed by the Cavendish professor. This characteristic is well brought out; day after day he would go his rounds of some three dozen research students, hearing their individual troubles and setbacks, but ready almost immediately with counsel and answer to their problems. Lord Morley once remarked, "Never say never"; certainly tradition has it that 'J. J.' never required any "notice of that question". Doubtless, in such an atmosphere as this came into being the powers of the Cavendish Laboratory-and all that it stands for, even apparent neglect not excepted-to train men for research.

Lord Rayleigh deliberately limits himself to discussing the era already indicated; but more than this, he bids us look at it with the eyes of those who were in it and about it. This is most salutary. At once, the value of such an approach is manifest, for it enables the great controversy of the times concerning the nature of cathode rays (corpuscular or wavelike ?) to be apprehended as it appeared to contemporary thought. Since then, there has been much uncertainty, both in principle and in detail. But in those days, nothing blurred the sharp outline which divided the two schools. Cathode rays had to be one thing or the other.

There seems little doubt that what imparted the initial impulse to these investigations was the feeling that in a highly rarefied gas conditions were likely to be less complex than in liquids and solids. The kinetic theory, too, was at hand to help in getting a clear view in the mind's eye of what exactly was happening. Hittorf apparently was the first to observe phosphorescence around the cathode. Meanwhile, broadly the British school-Varley, Crookes, Kelvin, to whom should be added George Francis Fitzgerald-upheld the corpuscular theory, whereas Lenard, Hertz and others on the Continent supported the wave-nature interpretation. Lenard showed that cathode rays could penetrate a thin aluminium window. This was something of a reverse for the corpuscular upholders, but Thomson inclined to the opinion, Lord Rayleigh says, that an explanation might be found in the generation of a derived stream of particles on the far side. In 1895 Perrin performed his well-known experiment (somewhat akin to Faraday's ice-pail) and Thomson made a crucial extension to it. In these ways it appeared inescapable that cathode rays were in fact transporting negative electricity, and were thus essentially particles. The final stages, leading up to $(\mathrm{m} / \mathrm{e})$, need no recapitulation here.

It is noteworthy that Thomson was always somewhat attracted by the border-country between physics and chemistry ; indeed a dissertation having a strong sympathy in that direction won him his fellowship at the first attempt. Seen at this angle, it is more than fitting that such a lecture as we are now considering should have materialized under the ægis of the Chemical Society. Perhaps with this in view, Lord Rayleigh dwells almost exclusively upon his subject's distinction as an experimenter. But Thomson's contributions to mathematical physics were no less remarkable; for example, the discovery in the early 'nineties of electromagnetic momentum. In this may be seen a pre-condition for the rise of the great edifice in recent years, associated particularly with the names of Born and Dirac. Altogether, truly a momentous achievement. Then in 1918, on the advice tendered by Mr. Lloyd George to the Crown, 'J. J.' left the Cavendish for Trinity Lodge, there to gain new affections and new triumphs of a different kind; and so it was, until the end came on August 30, 1940, in his eighty-fifth year.

\section{F. IAN G. RaWLINS.}

\section{CYTOLOGICAL CRITERIA OF MAMMALIAN ENDOCRINE ACTIVITY}

\section{BY C. L. FOSTER}

Department of Biology, Middlesex Hospital Medical School

A CONSIDERATION of the development of endocrine histology throws considerable light both upon the problems which have confronted the investigator and the way in which attempts have been made to solve them. When the physiological significance of the endocrines was less understood than it is now, their histological descriptions were relatively simple. For example, in the anterior lobe of the pituitary two chromophilic and one chromophobic type of cell were described. As the gland came to be investigated in the light of an increasing knowledge of its physiological activities and with improved techniques, the complexity of the histological picture increased. Transition cells between chromophobe and chromophil have been recognized in many animals investigated ${ }^{1,2,3}$, and in the $\operatorname{dog}^{4}$ dark and light varieties of the basophil cells have been described, as have special carmine acidophils in the cat ${ }^{5}$. In a like manner, the original principal and oxyphil cells of the human parathyroid ${ }^{6}, 7$ have each been divided into two types-dark and light; osmiophilic and non-osmiophilic cells have been described in what 